\title{
Evaluate of braze joint strength and microstructure characterize of titanium-CP with Ag-based filler alloy
}

\author{
E. Ganjeh a,f,*, H. Sarkhosh ${ }^{\text {b,f }}$, H. Khorsand ${ }^{a}$, H. Sabet ${ }^{c}$, E.H. Dehkordi ${ }^{\text {d }}$, M. Ghaffari ${ }^{\text {e }}$ \\ ${ }^{a}$ Material Division, Faculty of Mechanical Engineering, K.N. Toosi University of Technology, Tehran, Iran \\ ${ }^{\mathrm{b}}$ Faculty of Biomedical Engineering, Amirkabir University of Technology, Tehran, Iran \\ ${ }^{\mathrm{c}}$ Metallurgical Department, Islamic Azad University - Karaj Branch, Karaj, Iran \\ ${ }^{\mathrm{d}}$ Faculty of Engineering, University of Applied and Scientific Shahr-e-Kord, Iran \\ e Department of Electrical and Electronics Engineering, UNAM - National Institute of Materials Science and Nanotechnology, Bilkent University, Ankara 06800, Turkey \\ ${ }^{\mathrm{f}}$ Young Researchers Club, Tehran North Branch, Islamic Azad University, Tehran, Iran
}

\section{A R T I C L E I N F O}

\section{Article history:}

Received 24 December 2011

Accepted 28 January 2012

Available online 7 February 2012

\section{Keywords:}

D. Brazing and soldering

F. Microstructure

G. Scanning electron microscopy

\begin{abstract}
A B S T R A C T
This research investigates the influences of brazing parameters (temperature and time) on microstructures and the mechanical properties of commercially pure (CP) titanium sheet when it is brazed with CBS34 (Ag-20Cu-22Zn-24Cd) braze filler foil. Brazing was performed in a conventional atmosphere control furnace. The brazing temperatures and holding times employed in this study were $800-870{ }^{\circ} \mathrm{C}$ and $10-20 \mathrm{~min}$, respectively. The qualities of the brazed joints were evaluated by ultrasonic test and the microstructure and phase constitution of the bonded joints were analyzed by means of metallography, scanning electron microscope (SEM) and X-ray diffraction (XRD). The mechanical properties of brazed joints were evaluated by microhardness and shear tests. The diffusion between $\mathrm{Ti}, \mathrm{Ag}, \mathrm{Cu}, \mathrm{Zn}$ and $\mathrm{Cd}$ from substrate and braze alloy, developed a strong reaction between each other. A number of intermetallic phases, such as $\mathrm{TiCu}$ and $\mathrm{Ti}_{2} \mathrm{Cu}$ in the $\mathrm{Ag}-\mathrm{Zn}$ solid solution matrix have been identified especially at $870^{\circ} \mathrm{C}-20 \mathrm{~min}$. Both the brazing temperature and the holding time are critical factors for controlling the microstructure and hence the mechanical properties of the brazed joints. The optimum brazing parameters was achieved at $870{ }^{\circ} \mathrm{C}-20 \mathrm{~min}$. Based on the shear test result, all cracks propagate along the brittle intermetallic compounds like $\mathrm{Ti}_{2} \mathrm{Cu}$ in the reaction layer which typically are composed of quasi-cleavage ( $\mathrm{Ag}-\mathrm{Zn}$ matrix) and brittle appearance.
\end{abstract}

(c) 2012 Elsevier Ltd. All rights reserved.

\section{Introduction}

Titanium and its alloys play an important role in many modern industries (especially in aerospace and gas turbine engines), due to their highly desirable performance characteristics, such as good strength to density ratio, low density, high creep, fatigue and corrosion resistance [1-5]. This property has developed transition joints of $\mathrm{Ti}$ to other engineering materials such as steel, nickel, and copper-based alloys [7]. Many titanium joining methods, including welding, brazing and diffusion welding have been developed. Among those, brazing is widely applied in aerospace manufacturing for brazed titanium parts in aircraft frames (honeycombs structure) and engines [5]. Titanium has a strong chemical affinity (very reactive material) for oxygen and a stable and tenacious oxide layer forms rapidly on its surface in comparison to other metals. At temperatures above $500^{\circ} \mathrm{C}$, the oxidation resistance of

* Corresponding author. Address: No. 15-19, Pardis Street, Mollasadra Avenue, Vanak Square, P.O. Box 19395-1999, Tehran, Iran. Tel.: +98 2188674741.

E-mail address: navidganjehie@sinakntu.ac.ir (E. Ganjeh). titanium decreases rapidly and it becomes highly susceptible to embrittlement by oxygen, nitrogen and hydrogen. Due to the fact that in titanium welding the temperature is more than $500{ }^{\circ} \mathrm{C}$ $\left(T_{\mathrm{m}}^{\mathrm{Ti}} \approx 1668{ }^{\circ} \mathrm{C}\right)$, it is subjected to oxidation [1]. Titanium, in medical implants, public facilities, photocatalyst and industrial pipelines the adhesion of bacteria onto the surfaces of numerous materials can lead to the formation of biofilms and the outbreak of infectious diseases [6].

The advantages of titanium brazing in comparison with welding are: a decrease of energy and heat input, the decrease of residual stress, a lighter weight structure and the absence of a heat affected zone (HAZ). In titanium brazing technology, it is recommended that the brazing temperature does not exceed the $\alpha-\beta$ transformation temperature (usually $880-910^{\circ} \mathrm{C}$ ) in order to preserve the original microstructural and mechanical property of the Ti base metal $[1-3,8]$. With decreasing time or temperature of brazing, erosion of the substrate and excessive growth of intermetallic phase at the interface will be significantly decreased or eliminated [9]. As mentioned, in the brazing of $\mathrm{Ti}$ and its alloys, the brazing temperature should be as low as possible, in order to retard the grain growth in 
the base metal and joint parts. Since the brazing temperature is determined by the melting temperature of the filler alloy, many experiments have been done $[5,10-13]$ on filler alloys with a decreased of the brazing temperature. One effective method of doing this is by adding alloying elements such as $\mathrm{Cu}, \mathrm{Zn}, \mathrm{Mn}, \mathrm{Be}$, and In to brazing fillers as well as producing fillers, in shapes of foil, powder, paste, or coat.

Other variables interfere with the brazing process such as the brazing temperature, holding time, braze alloy composition, filler metal thickness, and heating/cooling rate [14]. Other variables can interfere with the brazing process and play an important role. Furnace brazing in an inert gas or vacuum atmospheres is an ideal industry process for brazing due to its advantages [15,16].

(1) It is a method in which many variables (such as brazing temperature, time and atmosphere, and heating and cooling rate) can be easily controlled to ensure the repeatability of the process and guarantee a high-quality joint. (2) There is no requirement for skilled operators, flux, or post brazes cleaning. (3) Because a whole part is heated, distortion of the parts can be minimized or eliminated and (4) More than one joint per work piece can be brazed in a brazing cycle, but it requires an initial high cost investment and more energy for heating whole assembly.

Various brazing filler metal compositions have already been evaluated to braze Ti commercially pure (Ti-CP) $[12,17,18]$. Silver-based filler alloys have the advantage of a low melting point but there are several drawbacks such as the low strength and corrosion resistance in the joints when compared with titanium or zirconium based filler metals. The filler metal CBS34 (Ag20Cu-22Zn-24Cd, wt.\%), which has a similar composition to the BAg-2 (Ag-26Cu-21Zn-18Cd, wt.\%) filler alloy according to American Welding Society (AWS) A5.8 [19], can definitely be considered as a potential solution for brazing titanium and its alloys. Copper, zinc and cadmium are the main reasons for the decrease in the melting temperature of the filler metal.

Elrefaey and Tillmann [12] evaluated the effect of brazing time and temperature on microstructure and mechanical properties of Ti-CP in vacuum furnace by Incusil-ABA (Ag-27.2Cu-12.5In1.25Ti, wt.\%) $200 \mu \mathrm{m}$ filler foil, which had a melting range of $605-710^{\circ} \mathrm{C}$. The reported result for at a temperature of $800^{\circ} \mathrm{C}$ under all holding times was not acceptable. However, high strength values have been achieved at a temperature of $750{ }^{\circ} \mathrm{C}$ and the maximum shear strength (92.3 MPa) was obtained at a holding time of $90 \mathrm{~min}$. At a temperature of $710^{\circ} \mathrm{C}$, the brazed joint resulted in medium strength values. Several Ti-Cu intermetallic compound formations were the main cause for decreasing the strength. The predominant fracture morphology was described as a mixed dimple structure with tearing regions. This work focus on brazing Ti-CP at argon atmosphere as an inert gas and evaluate the effect of processing parameters (temperature and time) with Ag-based filler alloy (it has not been tested until now) on microstructure and mechanical properties. We investigated the joint mechanical properties by shear and micro hardness tests. The braze joint quality and microstructure were evaluated by an ultrasonic test, Light optical microscope (LOM) and scanning electron microscope (SEM)-EDS (Energy Dispersive Spectroscopy). Afterward, the fracture surface was analyzed with X-ray diffraction (XRD) and SEM.

\section{Materials and design of experiments}

\subsection{Materials}

The base metal used in this research was $1.5 \mathrm{~mm}$ thick Ti-CP with $890^{\circ} \mathrm{C} \quad \alpha \rightarrow \beta$ transformation. $85 \mu \mathrm{m}$-thicks Ag-based (CBS34) has been selected as the brazing alloy. The nominal chemical composition of the base metal and filler are given in Tables 1 and 2, respectively. Single lap shear specimens with $10 \mathrm{~mm}$ width in the reduced cross-section were brazed with overlapping $4.5 \mathrm{~mm}$ (3T) according to the JIS Z 3192 [20] standard, by means of a wirecutting machine. Also, the plate was cut into $10 \mathrm{~mm} \times 15 \mathrm{~mm}$ chips for microstructure analysis. The parent metals were first polished with $\mathrm{SiC}$ papers up to 600 grit and subsequently cleaned by an ultrasonic bath using acetone for $20 \mathrm{~min}$ at $50{ }^{\circ} \mathrm{C}$ as the solvent prior to furnace brazing. The brazing foils were cleaned in acetone before brazing and then sandwiched between the overlapping areas of the parent metals. The mechanical properties of Ti-CP base metal are mentioned in Table 3.

\subsection{Fillers melting behavior}

The melting behaviors of the filler foil were examined by a differential thermal analyzer (DTA, Shimadzu DTG-60H) from room temperature up to $900^{\circ} \mathrm{C}$ at a heating rate of $20^{\circ} \mathrm{C} / \mathrm{min}$ in a dynamic atmosphere of air $(20 \mathrm{ml} / \mathrm{min})$. The melting ranges of the brazing filler metal are presented in Table 4 .

\subsection{Brazing condition}

The schematic of atmosphere control furnace brazing (Iranian patent number: 72122) that was newly designed and used in this research is illustrated in Fig. 1. At first, the chamber was evacuated for about $10 \mathrm{~min}$ to approximately $1 \mathrm{mPa}$ and then purged with high purity argon gas at a static flow which was controlled by a volume manometer. Through brazing, the samples were compressed and loaded by a $0.3 \mathrm{MPa}$ pressure. Thermocouple (Chromel-Alumel) was connected to the samples proximity to the lap joint area (hot zone). Also, an ultra-high purity argon (99.999) was utilized throughout the heating/brazing/cooling cycle.

In conventional furnace brazing the cooling/heating rate could be adjusted to a maximum of $30^{\circ} \mathrm{C} / \mathrm{min}$ [16]. In titanium brazing, the cooling and heating rate must be as high as possible to reduce both excessive growth of intermetallic phase in the brazed joint and erosion of the substrate [21]. Hence it is important to reduce the brittle phases to assure the structure integrity by optimizing the brazing specification. Moreover, the quick cooling method should not be used because it creates thermal cracks and decrease the strength [14]. Therefore, it is essential to use a furnace that has high cooling/heating rate. The high heating rate was solved by using a $2500 \mathrm{~W}$ high power furnace. The highest cooling rate was achieved by introducing argon gas during the cooling part of the brazing cycle. Consequently, the heating and cooling rates during the brazing cycles were reached at $65^{\circ} \mathrm{C} / \mathrm{min}$.

In the research done by Shiue et al. [13], a new cooling method for vacuum brazing was performed by quick cooling via filling the furnace with dry nitrogen and starting up the wind cooling system at the same time. This process for cooling samples is more expensive than the argon gas procedure we used in this investigation. This system is more economical and has industrial attraction. The joints were fixed with a steel clamp and then carefully placed into the furnace. The width of overlap was kept at $4.5 \mathrm{~mm}$ (3T) since it is recommended to use a lap width of no more than three times the thickness of the base metals in order to achieve high strength for the joint [22]. Elrefaey and Tillmann [22] proved that the average shear strength of the joint showed a general tendency to decrease

Table 1

Chemical composition (wt.\%) of the Ti-CP.

\begin{tabular}{lllllll}
\hline Alloy & $\mathrm{C}$ & $\mathrm{O}$ & $\mathrm{Fe}$ & $\mathrm{N}$ & $\mathrm{H}$ & $\mathrm{Ti}$ \\
\hline CP titanium & 0.1 & 0.2 & 0.08 & 0.15 & 0.01 & Bal. \\
\hline
\end{tabular}


Table 2

Chemical composition (wt.\%) of the filler foil which used in this research.

\begin{tabular}{llll}
\hline CBS34 (L-Ag34Cd - Din 8513) & & \\
\hline $\mathrm{Ag}$ & $\mathrm{Cu}$ & $\mathrm{Zn}$ & $\mathrm{Cd}$ \\
\hline 34 & 20 & 22 & 24 \\
\hline
\end{tabular}

Table 3

Mechanical properties of Ti-CP base metal.

\begin{tabular}{lll}
\hline Yield strength (Mpa) & Tensile strength (Mpa) & Elongation (\%) \\
\hline 345 & 433 & 22
\end{tabular}

Table 4

Melting behaviors of the filler foil used in the experiment.

\begin{tabular}{ll}
\hline Filler braze alloys & CBS34 \\
\hline Solidus/liquidus temperature $\left({ }^{\circ} \mathrm{C}\right)$ & $610 / 705$ \\
\hline
\end{tabular}

with increasing lap width. It indicated that the average shear stress in the lap joint decreases and Von Mises stress was successfully utilized with the increase of the overlap width. As the overlaplength of joint increases, the Von Mises stress distribution becomes less uniform. The middle portion of the overlap contributes less to the overall load-carrying capacity of the joint, whereas the ends of the joint become overloaded. The non-uniform stress distribution in the lap joint causes the decreasing of the shear strength [23]. Table 5 summarizes all furnace brazing variables used in the experiment.

\subsection{NDT of brazed joint}

The ultrasonic test was carried out by the use of a probe which generated a longitudinal wave of $22 \mathrm{MHz}$ in frequency. Measurements were performed on the "Krautkramer Branson" thickness measurement according to AWS-C3.8 [24], which is developed at the Iran air organization with a standard CL3 DL, transducer (Alpha, Aerotech) was attached to the surface of the brazed joint. To minimize the impact of contact pressure on the PAW amplitude, a thin layer of high-viscosity couplant was used.

\subsection{Microstructure observation}

Standard grinding and polishing sample preparation procedure was applied [25] and Kroll's reagent $\left(3 \mathrm{ml} \mathrm{HF}+6 \mathrm{ml} \mathrm{HNO}_{3}+100 \mathrm{ml}\right.$
Table 5

Summary of furnace brazing variables used in the experiment.

\begin{tabular}{llll}
\hline Brazing time $(\min ) / \operatorname{temp}\left({ }^{\circ} \mathrm{C}\right)$ & 800 & 850 & 870 \\
\hline 10 & $\mathrm{~S} / \mathrm{UT}$ & $\mathrm{S} / \mathrm{M} / \mathrm{UT} / \mathrm{H}$ & $\mathrm{S} / \mathrm{M} / \mathrm{UT} / \mathrm{H}$ \\
20 & $\mathrm{~S} / \mathrm{M} / \mathrm{UT}$ & $\mathrm{S} / \mathrm{M} / \mathrm{UT} / \mathrm{H} / \mathrm{X}$ & $\mathrm{S} / \mathrm{M} / \mathrm{UT} / \mathrm{H} / \mathrm{X}$
\end{tabular}

S: shear test specimen.

M: metallurgical observation specimen.

UT: ultrasonic test.

$\mathrm{H}$ : microhardness measurement.

$\mathrm{X}$ : XRD analyze.

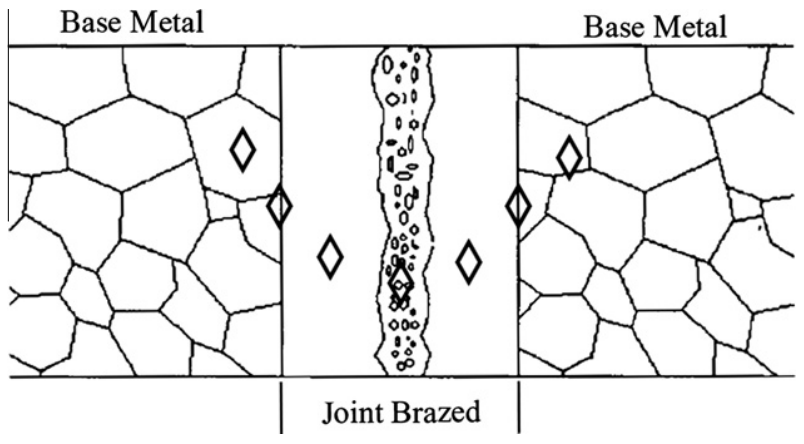

Fig. 2. Schematic representation of the profile microhardness testing.

$\mathrm{H}_{2} \mathrm{O}$ ) was used to evaluate the microstructures by a light optical microscope. The cross-section of the brazed specimens was examined using a VEGA/TESCAN scanning electron microscope, equipped with an energy dispersive spectroscopy (EDS) for element distributions, chemical and phase analysis. An Equinox 3000 (Inel, France) X-ray diffractometer (XRD) was applied for fracture analysis of the selected furnace brazed specimens. The $\mathrm{Cu} K_{\alpha}$ was chosen as the X-ray source, and was operated at a voltage of $40 \mathrm{kV}$ and a current of $40 \mathrm{~mA}$ with the scan range between $20^{\circ}$ and $110^{\circ}$. The X-ray diffraction pattern was recorded and identified based on the powder diffraction file (PDF).

\subsection{Mechanical testing}

The shear test was performed using a Zwick/Reoll Hct 400/25 dynamic testing machine with a constant crosshead speed of $0.5 \mathrm{~mm} / \mathrm{min}[7,8]$. At least two shear test specimens were performed for each brazing condition. Failure analysis of the brazed specimen after the shear test was investigated using the SEM and EDS analyses. Micro hardness measurements were made using a micro hardness tester (Wolpert Instron) with a load of $100 \mathrm{~g}$ and

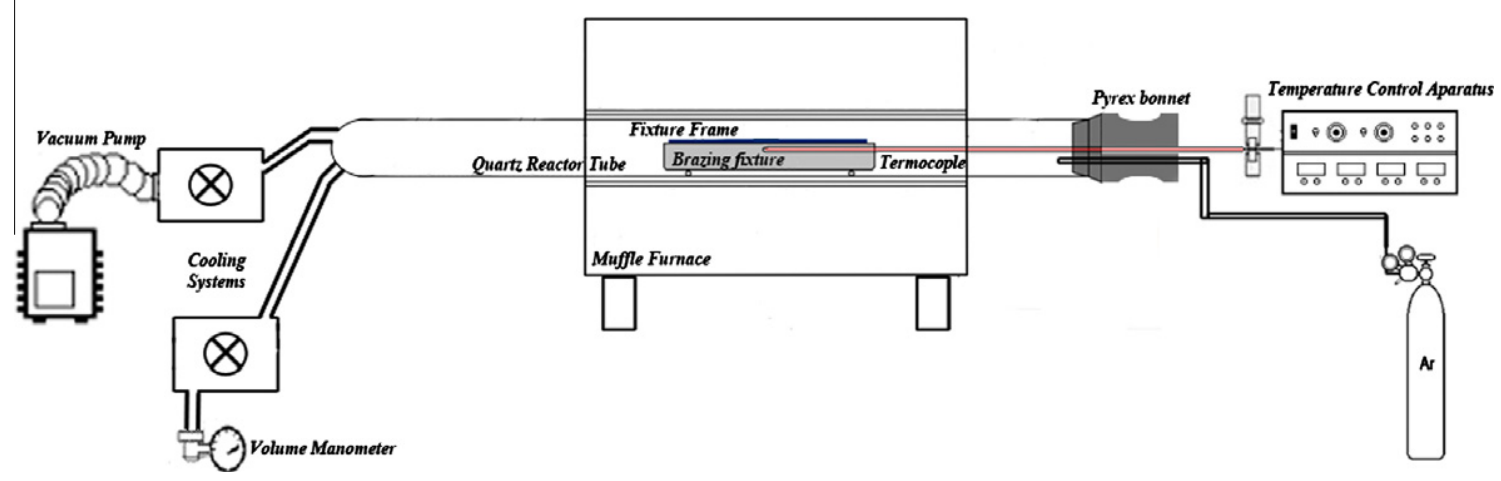

Fig. 1. Schematic of atmosphere control furnace for brazing. 
a dwell time of $35 \mathrm{~s}$. The details grid for micro hardness is illustrated in Fig. 2.

\section{Results and discussion}

\subsection{Microstructure observations}

Brazed joints were successfully formed in all the studied combinations of brazing temperatures and holding times. According to the ultrasonic test results, sound joints were obtained without any voids or cracks along joints only for samples brazed at $850^{\circ} \mathrm{C}$ and $870^{\circ} \mathrm{C}$, as demonstrates in Table 6. Even though the brazing filler metal could melt at a brazing temperature of $800{ }^{\circ} \mathrm{C}$ which is higher than the temperature of the solidus and liquidus in the filler metal but evaporation of cadmium and some of zinc in the braze alloy established pores or voids in the brazed joint. $\mathrm{Cd}$ and $\mathrm{Zn}$ have low melting and boiling points [26]. Therefore, at higher temperatures, they evaporated and porosity remained in the joint. This result is in agreement with the ultrasonic tests according to Table 6. A typical form of this defect is shown in Fig. 3.

Fig. 4 shows SEM backscattered electron images (BEIs) of the furnace brazed at $850^{\circ} \mathrm{C}$ for $10 \mathrm{~min}$. Moreover, a quantitative overview of the chemical analyses (EDS) in atomic percentage for the different regions is provided in Table 7 . Ag-rich liquid flows to the joint zone at an elevated temperature and it is responsible for filling the pores. Consequently, quantities of the voids have declined. There are three distinct layers observed at the braze joint, as shown in Fig. 4. At the titanium/brazed alloy interface, thin layers of $\beta-\mathrm{Ti}(\mathrm{Ti}-\mathrm{Ag})$ phase were clearly distinguished in Fig. 4a. One of the main phases presented in the brazed area, region II in Fig. 4, is a $\mathrm{Ti}-\mathrm{Cu}$ intermetallic phase containing low percentages of $\mathrm{Ag}$ and $\mathrm{Zn}$. The stoichiometry of $\mathrm{Cu} / \mathrm{Ti}$ ratio at this region is very close to $\mathrm{Ti}_{2} \mathrm{Cu}$. Migration of $\mathrm{Ag}, \mathrm{Cu}$, and $\mathrm{Cd}$ (strong $\beta$-stabilizing elements as noted in Table 8) in the titanium substrate lowers the eutectoid transformation temperature of $\mathrm{Ti}$ [27]. The presence of these alloying elements in a braze alloy is the main reason for the formation of $\mathrm{Ti}_{2} \mathrm{Cu}$ phase at a lower temperature. The presence of alloying elements in a braze alloy decreases the brazing temperature and consequently affects the peritectic reaction temperature by consuming copper from braze alloy, especially with zinc. Finally, at region III, a matrix of $\mathrm{Ag}$ solid solution, rich in $\mathrm{Cd}$ and $\mathrm{Zn}$, is present in high quantity with a low amount of titanium and copper through the brazed joint. The ternary $\mathrm{Ag}-\mathrm{Cd}-\mathrm{Zn}$ phase diagram [28] indicates that this phase is Ag-rich. Since there is no Ti content in filler alloy, it is expected that Ti atoms are transported from substrate via diffusion into the molten braze alloy.

SEM-backscattered electron images (BEIs) at a higher brazing holding time and temperature (Fig. 5) differed significantly from the sample which was brazed at $850^{\circ} \mathrm{C}-10 \mathrm{~min}$. The composition of different phases at brazed joint has been determined by EDS analyses and is listed in Table 9 . It is clear that a continuous reaction layer between the brazed seam and the titanium substrate was formed. In addition, the reaction layer has increased in thickness after the brazing temperature was prolonged. Different layers

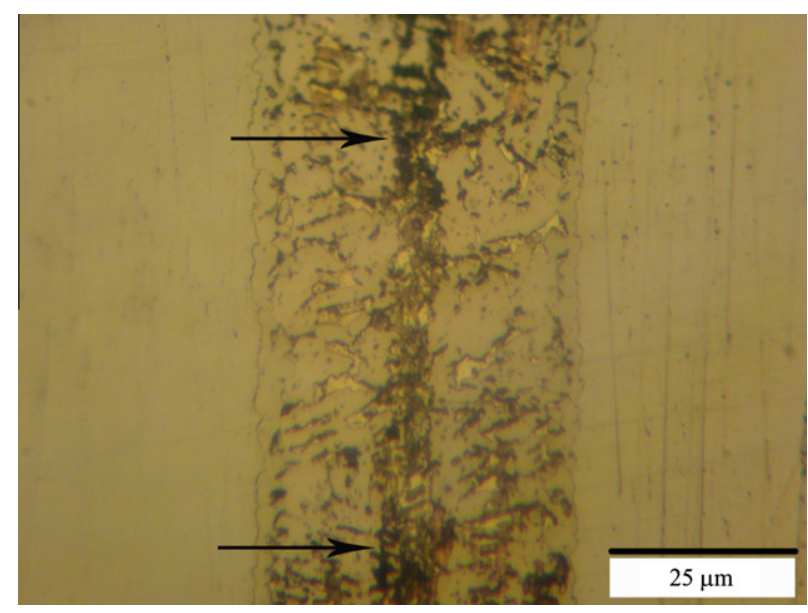

Fig. 3. Microstructure of brazed joint at $800^{\circ} \mathrm{C}$ for $20 \mathrm{~min}$. the pores were clearly observed and indicated by arrows.

of Ti-Cu intermetallic reaction layers appeared between the brazed alloy and titanium substrate, whose thickness of TiCu intermetallic phase increased after the brazing time or temperature, had been extended. The growth of the interfacial reaction layer resulted in the loss of elements in the braze alloy. According to the layers chemical analyses illustrated in Table 9 and the extrapolated data from $\mathrm{Cu}-\mathrm{Ti}$ and $\mathrm{Ti}-\mathrm{Ag}$ phase diagrams (Table 8) [28], both copper and silver preferred to solute in $\beta$-titanium. Afterwards, the solid solutions from these elements were able to be generated and the intermetallic compounds, such as $\mathrm{Ti}_{2} \mathrm{Cu}$, TiCu and/or TiAg, could be developed. In addition, the titanium diffusion from the titanium side toward the braze metal and the diffusion of $\mathrm{Ag}$ and $\mathrm{Cu}$ from braze alloy to titanium substrate were the main controlling factors to building these intermetallic phases. As shown in Fig. 5a and b, with increasing temperature and time, the Ag solid solution matrix contracted, owing to the release of $\mathrm{Cu}$, to form more intermetallic phases with Ti. The chemical analysis of this region was lower in $\mathrm{Ag}$ compared to its equivalent region at a lower brazing time (region III). Fig $5 c$ and $d$ shows that interfacial reaction layers like $\beta-\mathrm{Ti}, \mathrm{Ti}_{2} \mathrm{Cu}$, TiCu formed at high brazing times. They are labeled with 1,2 and 3 respectively. Formation of region 1 is owing to the lower solubility of $\mathrm{Ag}$ in $\alpha$-Ti than in $\beta$-Ti, as noted in Table 8 . The $\beta$-Ti takes the form of bright needles, whereas the $\alpha$-Ti has a dark plate-like structure between the needles of $\beta$-Ti.

Titanium is strongly associated with $\mathrm{Cu}$ and forms a varied $\mathrm{Cu}-$ Ti reaction layers at the interface. Therefore, $\mathrm{Ti}_{2} \mathrm{Cu}$ and $\mathrm{TiCu}$ formed at higher brazing times were thick and consumed most of the copper in the brazed zone. Increasing the soak time from $10 \mathrm{~min}$ to 20 min leads to an excessive growth of TiCu phase (see Fig. 5). Also this was displayed in another research [29]. It is stated elsewhere [30] that the growth rate of $\mathrm{TiCu}$ is much faster than that of $\mathrm{Ti}_{2} \mathrm{Cu}$ in temperature above $850^{\circ} \mathrm{C}$. Accordingly, the minimum temperature and time needed to activate and generate $\mathrm{TiCu}$ phase in this research was $850^{\circ} \mathrm{C}$ and 20 min, respectively. It could be

Table 6

Results of ultrasonic tests for brazed joints with CBS34 braze alloy.

\begin{tabular}{|c|c|c|c|c|}
\hline Temp. $\left({ }^{\circ} \mathrm{C}\right)$ & Time (min) & Layer thickness (mm) & Joint thickness (mm) & Results \\
\hline 800 & 10 & 1.49 & 1.49 & Rej. \\
\hline 800 & 20 & 1.51 & 1.51 & Rej. \\
\hline 850 & 10 & 1.5 & 3.05 & Acc. \\
\hline 850 & 20 & 1.54 & 3.07 & Acc. \\
\hline 870 & 10 & 1.5 & 3.11 & Acc. \\
\hline 870 & 20 & 1.5 & 3.01 & Acc. \\
\hline
\end{tabular}



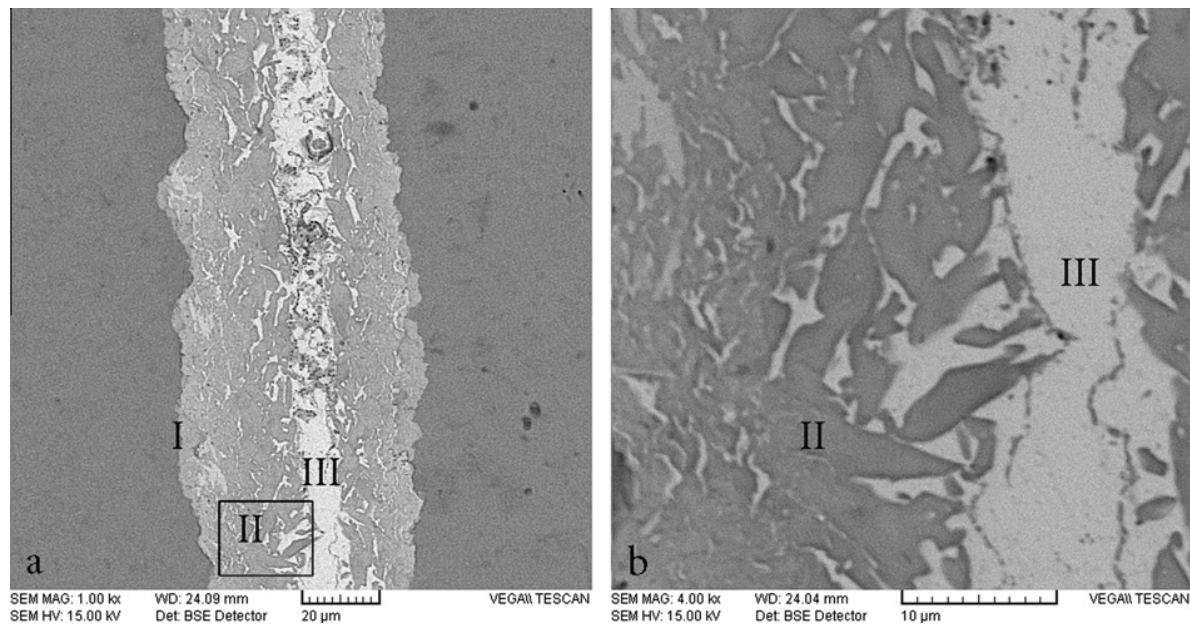

Fig. 4. SEM-BEIs of the brazed joints at $850^{\circ} \mathrm{C}$ for $10 \mathrm{~min}$ (a), (b) closer view of the rectangular area in (a).

Table 7

Chemical analyses at regions shown in Fig. 4.

\begin{tabular}{|c|c|c|c|c|c|c|}
\hline \multirow[t]{2}{*}{ Symbol } & \multicolumn{5}{|c|}{ Chemical analyses (at.\%) } & \multirow[t]{2}{*}{ Probable phase } \\
\hline & $\mathrm{Ti}$ & $\mathrm{Ag}$ & $\mathrm{Cu}$ & $\mathrm{Zn}$ & $\mathrm{Cd}$ & \\
\hline I & 89.1 & 6.3 & 2 & 2.6 & - & $\beta-\mathrm{Ti}$ \\
\hline II & 55.7 & 5.5 & 31.9 & 6.9 & - & $\mathrm{Ti}_{2} \mathrm{Cu}$ \\
\hline III & 1.2 & 84.5 & 0.8 & 4.2 & 9.3 & Ag-rich \\
\hline
\end{tabular}

Table 8

Data extrapolated from Ti-Ag, Ti-Cu, Ti-Cd and Ti-Zn binary phase diagrams [25,27].

\begin{tabular}{|c|c|c|c|c|}
\hline \multirow[t]{2}{*}{ Alloy system } & \multicolumn{2}{|c|}{ Maximum solubility in $\alpha-\mathrm{Ti}$} & \multicolumn{2}{|c|}{ Maximum solubility in $\beta$-Ti } \\
\hline & (at.\%) & Temp. $\left({ }^{\circ} \mathrm{C}\right)$ & (at.\%) & Temp. $\left({ }^{\circ} \mathrm{C}\right)$ \\
\hline $\mathrm{Ti}-\mathrm{Ag}$ & 5 & 855 & 18 & 1300 \\
\hline $\mathrm{Ti}-\mathrm{Cu}$ & 1.6 & 790 & 13.5 & 1005 \\
\hline $\mathrm{Ti}-\mathrm{Cd}$ & 6.5 & 782 & 28.5 & 870 \\
\hline Ti-Zn & 0 & - & 0 & - \\
\hline
\end{tabular}

concluded that the higher brazing temperature caused the interfacial reaction during brazing. Also these phases developed when Ti$\mathrm{CP}$ was vacuum brazed with $\mathrm{Ag}-27.2 \mathrm{Cu}-12.5 \mathrm{In}-1.25 \mathrm{Ti}$ filler foil [12]. Titanium and cadmium are proffered to solute in silver to form $\mathrm{Ag}$ solid solution matrix [28].

Therefore, by increasing the temperature and time of brazing, these elements would dissolve in each other. Afterwards, excessive $\mathrm{Ti}$ and $\mathrm{Zn}$ atoms were expelled from the $\mathrm{Ag}$-matrix and generated intermetallic compounds, like $\mathrm{TiCu}$ and $\mathrm{Ti}_{2} \mathrm{Cu}$ (labeled 4 and 5 in Fig. 5d), but were surrounded by a silver and zinc solid solution matrix. It is important to note that the $\mathrm{Zn}-\mathrm{Cu}, \mathrm{Cd}-\mathrm{Ag}$ and $\mathrm{Ag}-\mathrm{Zn}$ binary phase diagrams [28] show that silver is more soluble in cadmium and zinc when the temperature lowered. Likewise, the solubility of $\mathrm{Zn}$ in $\mathrm{Cu}$ is 39-32.5 wt.\% at the temperature range of $454-902{ }^{\circ} \mathrm{C}$. By decreasing the brazing temperature, which results in a higher cooling rate, these binary systems $(\mathrm{Zn}-\mathrm{Cu}, \mathrm{Cd}-\mathrm{Ag}$ and $\mathrm{Ag}-\mathrm{Zn}$ ) create a condition for containing some intermetallic phase in our matrixes. Subsequently, the shape of $\mathrm{TiCu}$ phase would change from a continuous layer to globular particles with an increase of temperature or time. Region 6 is a poorer $\mathrm{Ag}-\mathrm{Zn}$ solid solution matrix in contrast with region 5 , which contain a $\mathrm{Ti}_{2} \mathrm{Cu}$ intermetallic compound. The formation of interfacial TiCu and/or $\mathrm{Ti}_{2} \mathrm{Cu}$ phase results in the isolation of the molten braze and $\mathrm{Ti}$ substrate [21].

\subsection{Mechanical properties}

Fig. 6 shows the mechanical properties of brazed specimens with various brazing conditions. The shear strength of joints revealed a general tendency to increase with an increase in holding time and brazing temperature. The best mechanical properties were achieved at a temperature of $870{ }^{\circ} \mathrm{C}$ and at a holding time of $20 \mathrm{~min}$. They were equal to $164.2 \mathrm{MPa}$ for shear strength and $5.6 \%$ for elongation. It is well known that the shear strength is $\sim 0.6$ of maximum tensile strength [31]. Consequently the optimum shear strength is $63 \%$ of the base metal (the strength of Ti$\mathrm{CP}$ was $433 \mathrm{MPa}$ according to Table 3 ). The maximum shear strength is approximately twice the amount of strength reached by Elrefaey and Tillmann [12]. From a microstructural point of view, the change of joint strength within the brazing parameters was to a large extent dependent on the joint microstructure. The thickness and type of the reaction layer and intermetallic phases in between the substrate and brazed alloy are critical factors in determining the strength of the joints. Titanium mainly reacted with copper in all joints and formed almost the same kinds of $\mathrm{Ti}-\mathrm{Cu}$ intermetallic phases. It is obvious in Fig. 5a-d that with an increase in brazing temperature or time, the thickness of layers increased. It is suggested that the shear strength of the joint was influenced by the formation of the required reaction layer to achieve good strength for the brazed joint. The pores observed at a brazing temperature of $800{ }^{\circ} \mathrm{C}$ lowered the strength at this temperature. At the same time, the relative amount and percentage of the TiCu phase at a high temperature $\left(870^{\circ} \mathrm{C}\right)$ was very high compared to its content at lower temperatures $\left(850^{\circ} \mathrm{C}\right)$. For the specimen brazed at a temperature of $850{ }^{\circ} \mathrm{C}$, the thickness of the reaction layer, especially $\beta-\mathrm{Ti}$, was not enough to achieve a high strength for the joint. However, increasing the brazing time or temperature led to more wetting, interaction, or mutual diffusion at the interface, which reflected the high strength of the joint. Increasing the temperature to $870{ }^{\circ} \mathrm{C}$ led to an increase in the thickness of interaction layers, especially at a holding time of $20 \mathrm{~min}$. The main reason for the increased shear strength and elongation is because of the nature of the microstructure (Fig. 5d). The formation of hard intermetallic compounds, such as TiCu and $\mathrm{Ti}_{2} \mathrm{Cu}$ in a ductile of $\mathrm{Ag}-\mathrm{Zn}$ solid solution matrix, creates a metal matrix composite, which is reinforced with $\mathrm{TiCu}$ and $\mathrm{Ti}_{2} \mathrm{Cu}$. Indeed, these intermetallic compounds act as second-phase particles, which prevent moving dislocation and slip planes [32]. Small second-phase particles, distributed in a ductile matrix, are a common source of 

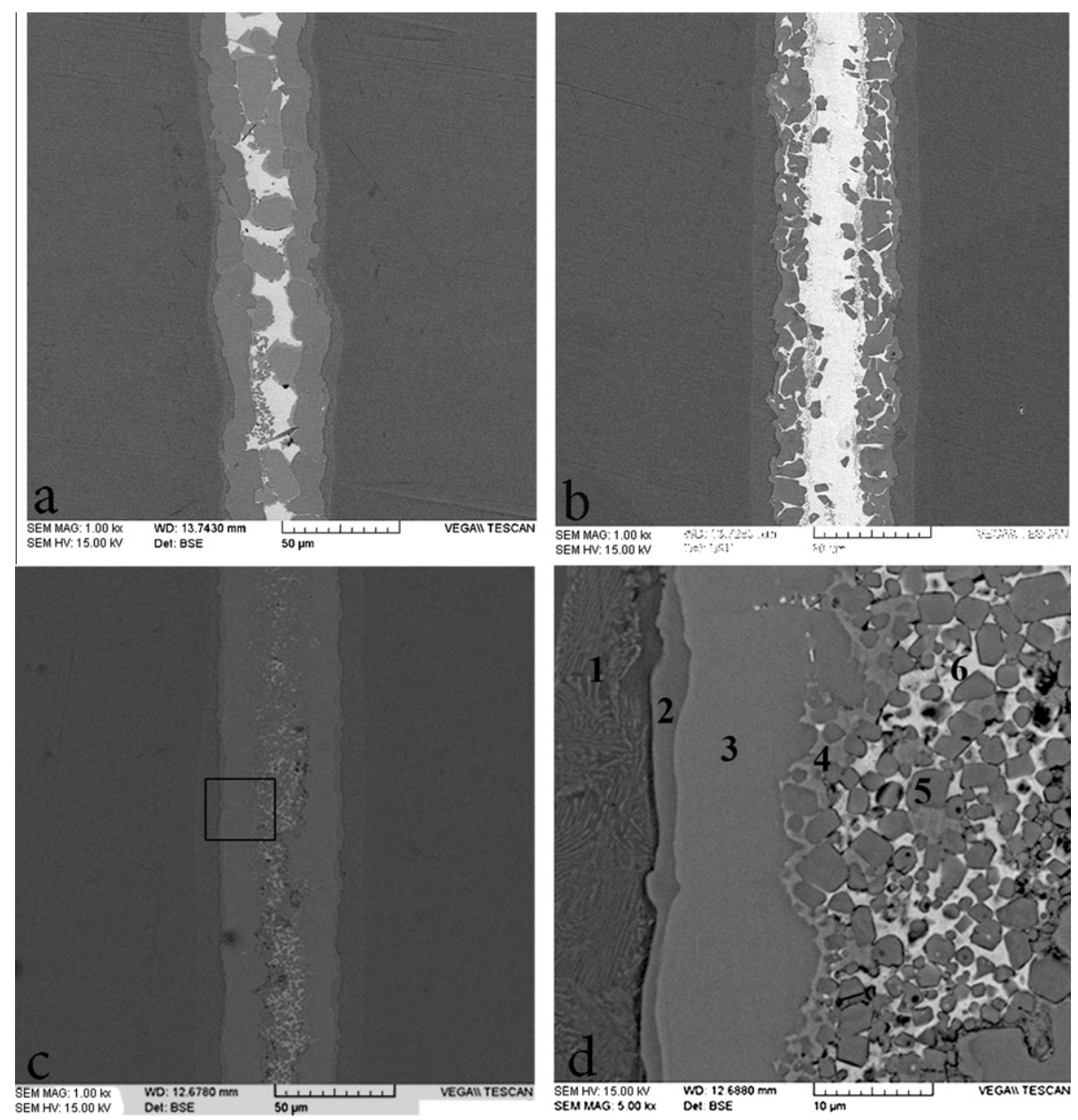

Fig. 5. SEM BEIs of brazed joints: (a) $850{ }^{\circ} \mathrm{C}-20 \mathrm{~min}$; (b) $870{ }^{\circ} \mathrm{C}-10 \mathrm{~min}$; (c) $870{ }^{\circ} \mathrm{C}-20$ min and (d) closer view of the rectangular area in (c).

Table 9

Chemical analyses at regions shown in Fig. 5.

\begin{tabular}{llccccl}
\hline \multirow{2}{*}{ Symbol } & \multicolumn{3}{l}{ Chemical analyses (at.\%) } & \multirow{2}{*}{ Probable phase } \\
\cline { 2 - 5 } & $\mathrm{Ti}$ & $\mathrm{Ag}$ & $\mathrm{Cu}$ & $\mathrm{Zn}$ & $\mathrm{Cd}$ & \\
\hline 1 & 90 & 6.3 & 2 & 1.4 & 0.3 & $\beta-\mathrm{Ti}$ \\
2 & 60.48 & 1.29 & 31 & 6.13 & 1.11 & $\mathrm{Ti}{ }_{2} \mathrm{Cu}$ \\
3 & 49.3 & 2.46 & 42.8 & 4.9 & 0.64 & $\mathrm{TiCu}$ \\
4 & 22 & 39.2 & 22.5 & 13.9 & 2.42 & $\mathrm{TiCu}$ rich in Ag-matrix \\
5 & 41.3 & 16.7 & 27.2 & 11.8 & 2.99 & $\mathrm{Ti}_{2} \mathrm{Cu}$ rich in Ag-Zn matrix \\
6 & 42.3 & 12.8 & 25.5 & 14.8 & 1.67 & $\mathrm{Ti}_{2} \mathrm{Cu}$ rich in Ag-matrix \\
\hline
\end{tabular}

alloy strengthening. Furthermore, the globular shape of these precipitations is another reason for the increase in shear strength [31].
The profile of Vickers microhardness of different zones of the brazed joints is shown in Fig. 7. Fig. 4a shows which microstructure of specimen, brazed at $850{ }^{\circ} \mathrm{C}-10 \mathrm{~min}$, contained $\mathrm{Ti}_{2} \mathrm{Cu}$ and Ag-rich phases. Fig. 7a shows that the microhardness value reaches $275 \mathrm{HV}$ for $\mathrm{Ti}_{2} \mathrm{Cu}$ and 105 for Ag-rich phases, (regions II and III) respectively. The increase in temperature and time of brazing is responsible for developing the $\mathrm{TiCu}$ intermetallic phase with the highest level of hardness (415 HV). Intermetallic compounds presented the highest hardness values at the interfacial region. The microhardness of the brazed joint at a temperature of $870{ }^{\circ} \mathrm{C}$ is shown in Fig. 7b. The microhardness indicates high values at the interfaces rather than the other areas, which is ascribed to the appearance of the TiCu phase. According to Fig. 5d, brazing at higher temperatures developed a thin layer of $\beta$-Ti between the base
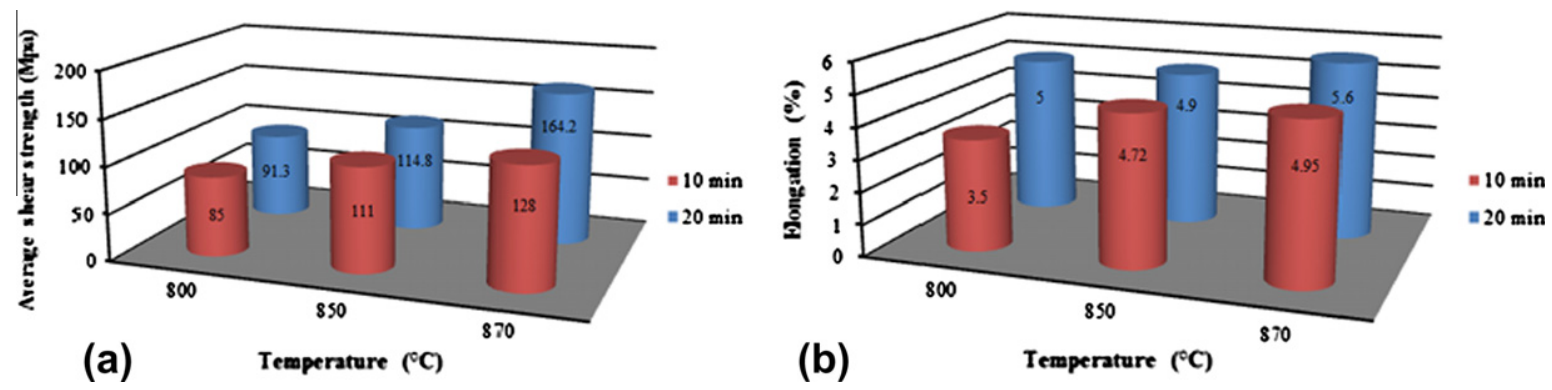

Fig. 6. Relation between (a) average shear strength and (b) elongation of the joint at different brazing temperature and time. 


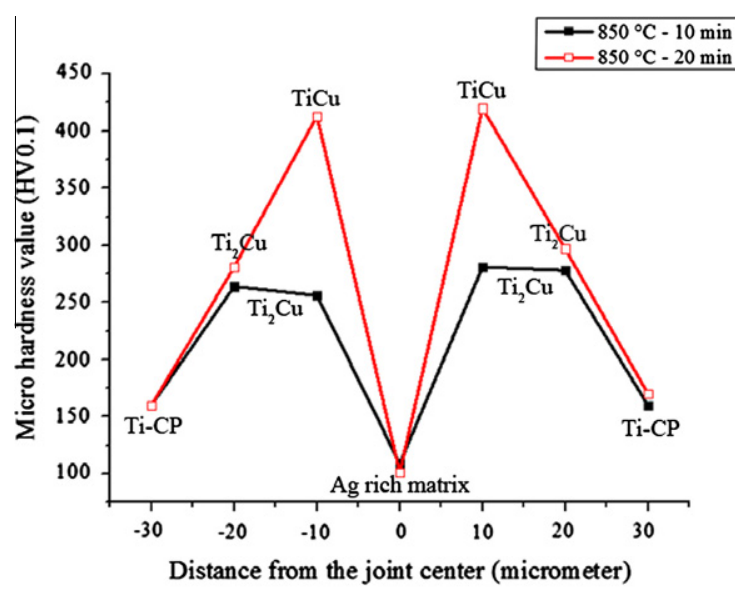

(a)

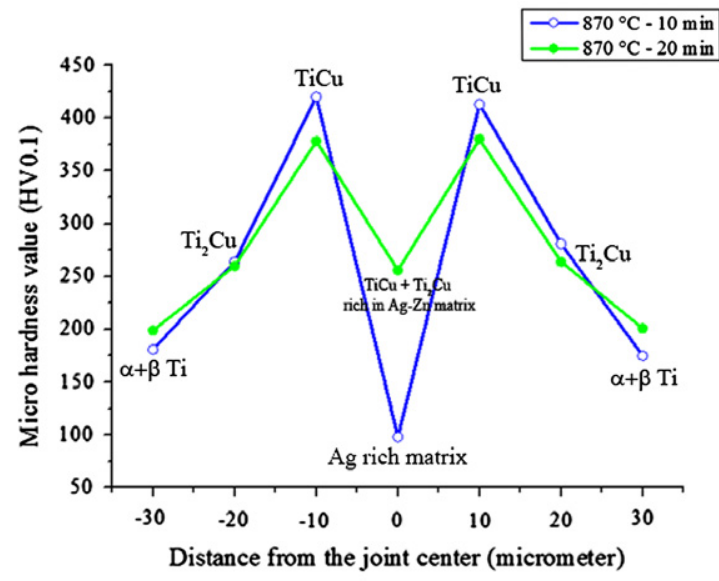

(b)

Fig. 7. Microhardness test of different zones of furnaced brazed joint at temperature of $850{ }^{\circ} \mathrm{C}$ and $870{ }^{\circ} \mathrm{C}$.

metal and reaction layers. Therefore the hardness value of this region (195 HV) is more than that of the Ti-CP base metal. Finally, brazing at $870{ }^{\circ} \mathrm{C}-20$ min established a microstructure of $\mathrm{Ti}_{2} \mathrm{Cu}$ and $\mathrm{TiCu}$ precipitations surrounded by an $\mathrm{Ag}-\mathrm{Zn}$ solid solution matrix (regions 4, 5 and 6 in Fig. 5d). It is important to note that the specimen which brazed at $870{ }^{\circ} \mathrm{C}-20$ min has uniform distribution hardness in comparison with the other ones, which is due to the increase in shear strength.

Fig. 8 shows that the joints failed mainly at the center of the braze alloy or interface at all brazing temperatures. The fracture path follows the interior of the braze alloy, mainly through the silver solid solution phase. With increased time and temperature, the fractured path is moving from the Ag-rich matrix to the interface due to the stronger bond between them. This implies that the TiCu intermetallic compound is a more harmful phase in comparison with the $\mathrm{Ti}_{2} \mathrm{Cu}$ phase. Fig. 9 shows the SEM fractograph and EDS results (Table 10) for different regions of the fractured surface. Many cracks indicated by the arrows (Fig. 9a and b) are initiated from the brittle $\mathrm{Ti}_{2} \mathrm{Cu}$ phase. The $\mathrm{Ag}-\mathrm{Zn}$ matrix phase shows that quasicleavage appearance, as shown in Fig. 9c and d next to the brittle $\mathrm{Ti}_{2} \mathrm{Cu}$ phase. Similarly, the quasi-cleavage dominated fractures of the $\mathrm{Ag}-\mathrm{Zn}$ matrix contained in the $\mathrm{TiCu}$ phase are widely observed in Fig. 9e. Accordingly, the quasi-cleavage fracture is favorable for the strength of the joint. The intermetallic compound formed at the titanium/braze interface reduced the strength of a bonded joint and caused the brittle fracture.

Furthermore, to confirm the presence of different phases especially those directly at the fracture surface, XRD from fractured surfaces at brazing temperatures of $850^{\circ} \mathrm{C}$ and $870{ }^{\circ} \mathrm{C}$ for 20 min were analyzed as it is shown in Fig. 10. XRD not only confirmed the presence of $\mathrm{Cu}$-Ti intermetallic compounds such as $\mathrm{TiCu}$ and $\mathrm{Ti}_{2} \mathrm{Cu}$, but also suggested the presence of different AgTi and $\mathrm{Ag}-\mathrm{Zn}$ phases at the fracture surface. For the specimen brazed at $850^{\circ} \mathrm{C}-20 \mathrm{~min}$ (Fig. 10), dominated $\mathrm{Ti}_{2} \mathrm{Cu}$ intermetallic phase were found at the fractured surface. Increasing the brazing temperature to $870{ }^{\circ} \mathrm{C}$ at the same time developed an $\mathrm{Ag}-\mathrm{Zn}$ phases in accordance with
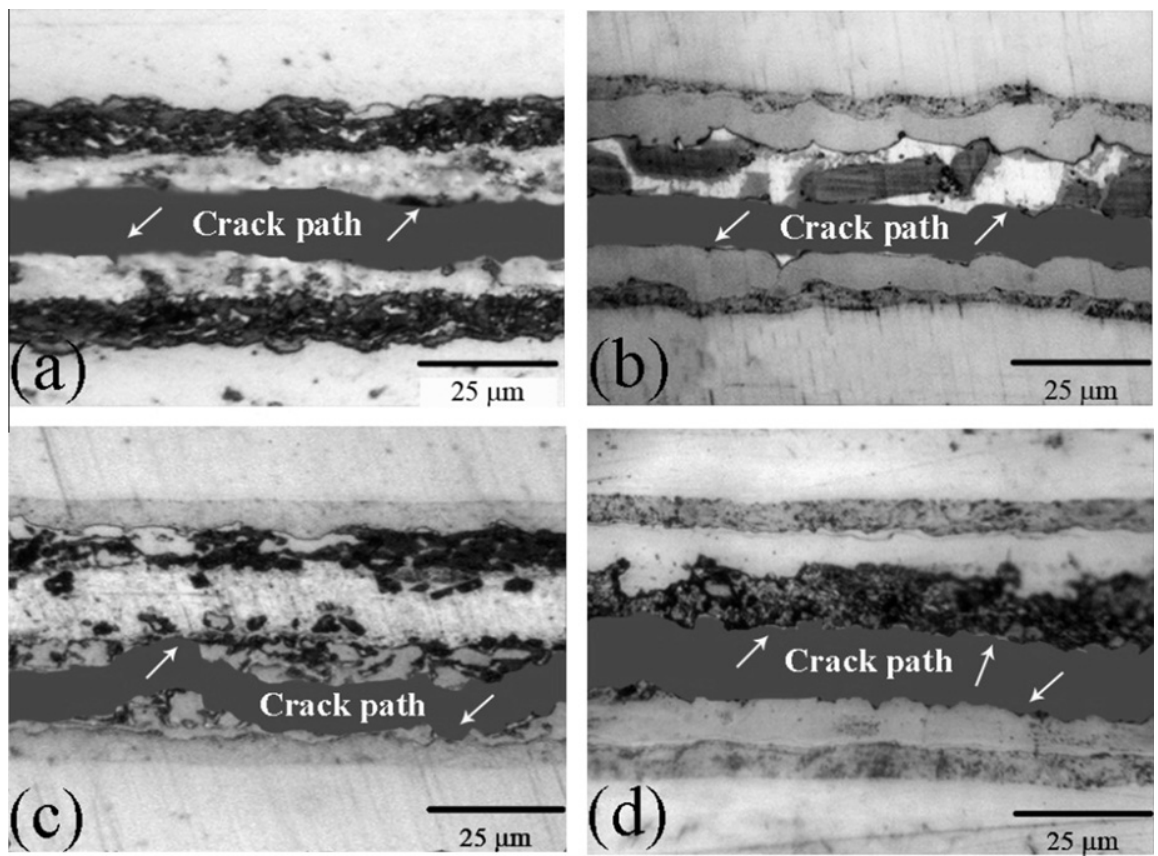

Fig. 8. Fracture paths after performing the shear test where (a) $850^{\circ} \mathrm{C}-10 \mathrm{~min}$, (b) $850{ }^{\circ} \mathrm{C}-20 \mathrm{~min},(\mathrm{c}) 870^{\circ} \mathrm{C}-10 \mathrm{~min}$ and $(\mathrm{d}) 870{ }^{\circ} \mathrm{C}-20 \mathrm{~min}$. 

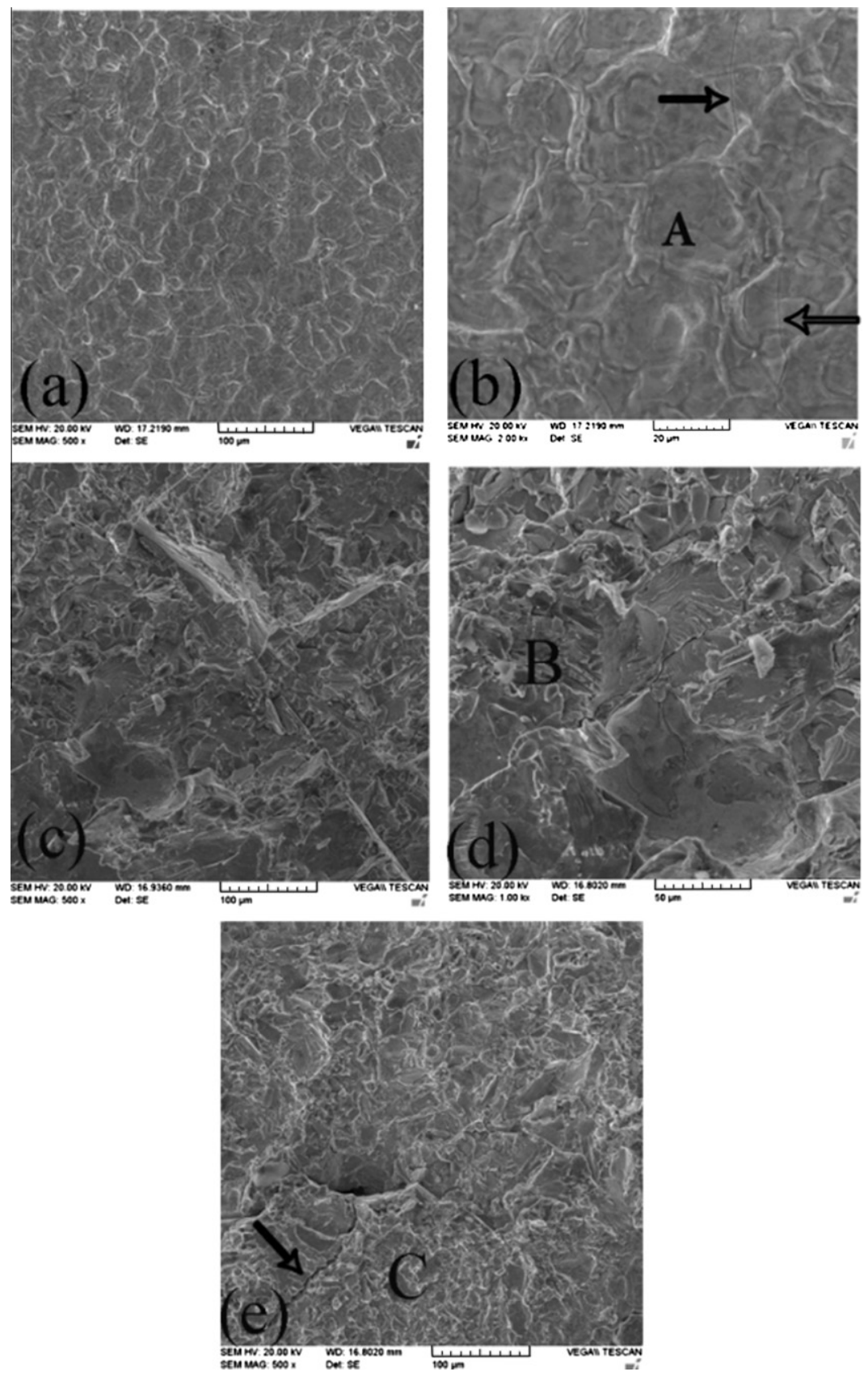

Fig. 9. Fracture morphology for brazed sample at (a and b) $850{ }^{\circ} \mathrm{C}-20 \mathrm{~min}$, (c and d) $870{ }^{\circ} \mathrm{C}-10 \mathrm{~min}$ and (e) $870{ }^{\circ} \mathrm{C}-20 \mathrm{~min}$; arrows are indicated to crack growth.

Table 10

Chemical analyses at regions shown in Fig. 9.

\begin{tabular}{llrlrlll}
\hline \multirow{2}{*}{ Symbol } & \multicolumn{6}{l}{ Chemical analyses (at.\%) } & \multirow{2}{*}{ Probable phase } \\
\cline { 2 - 5 } & $\mathrm{Ti}$ & \multicolumn{1}{c}{$\mathrm{Ag}$} & $\mathrm{Cu}$ & $\mathrm{Zn}$ & $\mathrm{Cd}$ & \\
\hline 1 & 51.3 & 8.2 & 31.9 & 6.3 & 2.3 & $\mathrm{Ti}_{2} \mathrm{Cu}$ \\
2 & 41.3 & 13.5 & 27.2 & 14.8 & 3.2 & $\mathrm{Ti}_{2} \mathrm{Cu}$ rich in $\mathrm{Ag}-\mathrm{Zn}$ matrix \\
3 & 46.4 & 4.5 & 33.6 & 14.7 & 0.8 & $\mathrm{TiCu}$ rich in $\mathrm{Ag}-\mathrm{Zn}$ matrix \\
\hline
\end{tabular}

$\mathrm{Ti}_{2} \mathrm{Cu}$ intermetallic compound. The existence of the $\mathrm{Ti}_{2} \mathrm{Cu}$ phase and the $\mathrm{Ag}-\mathrm{Zn}$ solid solution matrix in the specimen brazed at $870{ }^{\circ} \mathrm{C}$ leads to the occurrence of quasi-cleavage fracture instead of the brittle-dominated fracture type, as was observed in the specimen brazed at $850^{\circ} \mathrm{C}$.

\section{Conclusion}

Commercially pure titanium has been successfully brazed using CBS34 in an atmosphere control furnace. The microstructural evolution and bonding strength were experimentally assessed. The conclusions are summarized as follows:

(1) The joint mainly consists of $\beta-\mathrm{Ti}, \mathrm{Ti}_{2} \mathrm{Cu}$ and $\mathrm{Ag}$-rich phases at $850{ }^{\circ} \mathrm{C}-10 \mathrm{~min}$. The amount of $\mathrm{Ti}_{2} \mathrm{Cu}$ decreases with increasing brazing temperature and/or time due to the diffusion of $\mathrm{Cu}$ atoms from the braze alloy into the Ti substrate which developed $\mathrm{Ti}_{2} \mathrm{Cu}$ and $\mathrm{TiCu}$ intermetallic in an $\mathrm{Ag}-\mathrm{Zn}$ solid solution matrix. These phases were detected and confirmed by XRD analyses depending on the employed brazing parameters. 


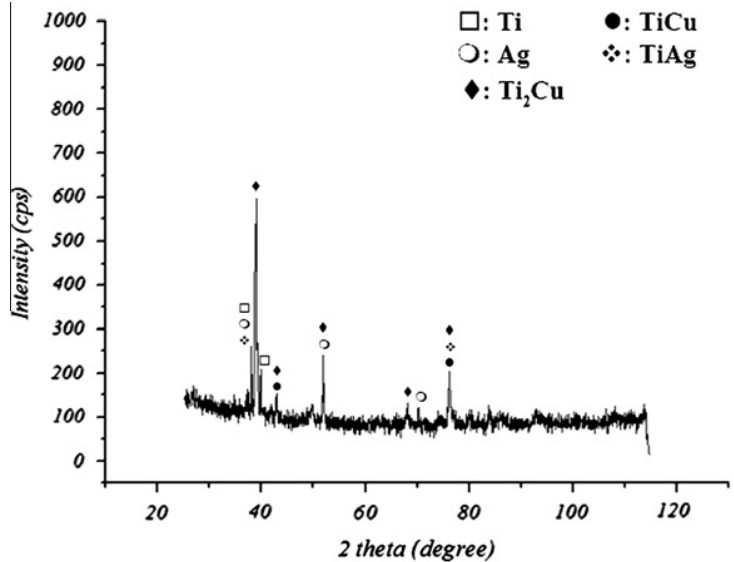

(a)

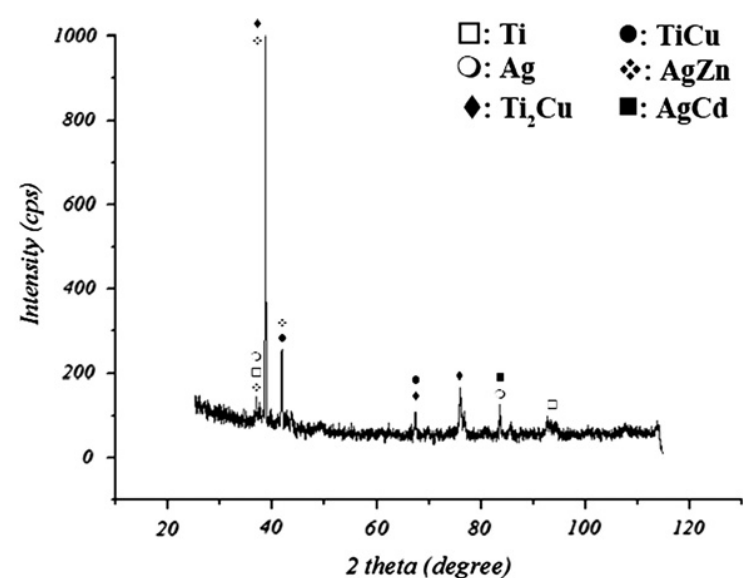

(b)

Fig. 10. XRD from fractured surfaces at brazing temperatures of $850{ }^{\circ} \mathrm{C}$ (a) and $870{ }^{\circ} \mathrm{C}$ (b) for $20 \mathrm{~min}$.

(2) At the same time, the shear strength of joints revealed a general tendency to increase with an increase in holding time. When the brazing temperature was increased to $870{ }^{\circ} \mathrm{C}$, the joint mainly comprised of $\beta-\mathrm{Ti}, \mathrm{Ti}_{2} \mathrm{Cu}$ and $\mathrm{TiCu}$ rich in Ag-Zn matrix.

(3) Joint furnace brazed at $870{ }^{\circ} \mathrm{C}-20 \mathrm{~min}$ demonstrates the highest shear strength up to $164.2 \mathrm{MPa}$ which is $63 \%$ strength of base metal. Microhardness measurements showed that $\mathrm{TiCu}$ phases are more hardened than $\mathrm{Ti}_{2} \mathrm{Cu}$ phases. Brazing at $870{ }^{\circ} \mathrm{C}-20$ min established uniform distribution hardness rather than the other brazing temperatures.

(4) High shear strength joints were fractured at the interface of the brazed alloy with substrate mainly in the Ag- $\mathrm{Zn}$ solid solution matrix and the fracture morphology for those kinds of joints presented quasi-cleavage characteristic.

\section{Acknowledgements}

The authors would like to thank the faculty of aerospace engineering for designing and manufacturing brazing fixtures, the advanced materials, and the nanotechnology research laboratory of K.N.T.U, and also the air line of Islamic republic of Iran (Iran Air) for their cooperation and for providing the experimental facilities. Also, the authors are grateful for the physical and mechanical properties laboratory in the faculty of biomedical engineering at AUT.

\section{References}

[1] Donachie MJ. TITANIUM: a technical guide. second ed. USA: ASM; 2000.

[2] Lutjering G, Williams JC. Titanium. 2nd ed. Berlin: Springer; 2007.

[3] Leyens C, Peters M. Titanium and titanium alloys fundamentals and applications. WILEY-VCH Verlag GmbH; 2003.

[4] Shapiro AE, Flom YA. Brazing of titanium at temperatures below $800{ }^{\circ} \mathrm{C}$ : review and prospective applications. In: Proceedings of 8th international conference in brazing, high temperature brazing and diffusion welding. Germany: Aachen; 2007. p. 254-67.

[5] Shapiro A, Rabinkin A. State of the art of titanium-based brazing filler metals Welding J 2003:36-43.

[6] Ghaffari M, Tan PY, Oruc ME, Tan OK, Tse MS, Shannon M. Effect of ball milling on the characteristics of nano structure $\mathrm{SrFeO}_{3}$ powder for photocatalytic degradation of methylene blue under visible light irradiation and its reaction kinetics. Catal Today 2010.
[7] Lee JG, Kim GH, Lee MK, Rhee CK. Intermetallic formation in a Ti-Cu dissimilar joint brazed using a Zr-based amorphous alloy filler. Intermetallics 2010;18:529-35.

[8] Lee JG, Choi YH, Lee JK, Lee GJ, Lee MK, Rhee CK. Low-temperature brazing of titanium by the application of a $\mathrm{Zr}-\mathrm{Ti}-\mathrm{Ni}-\mathrm{Cu}-\mathrm{Be}$ bulk metallic glass (BMG) alloy as a filler. Intermetallics 2010;18:70-3.

[9] Du YC, Shiue RK. Infrared brazing of Ti-6Al-4V using two silver-based braze alloys. J Mater Process Tech 2009;209:5161-6.

[10] Chang CT, Wu ZY, Shiue RK, Chang CS. Infrared brazing Ti-6Al-4V and SP-700 alloys using the Ti-20Zr-20Cu-20Ni braze alloy. Mater Lett 2007;61:842-5

[11] Chang CT, Du YC, Shiue RK, Chang CS. Infrared brazing of high-strength titanium alloys by $\mathrm{Ti}-15 \mathrm{Cu}-15 \mathrm{Ni}$ and $\mathrm{Ti}-15 \mathrm{Cu}-25 \mathrm{Ni}$ filler foils. Mater Sci Eng A 2006;420:155-64.

[12] Elrefaey A, Tillmann W. Effect of brazing parameters on microstructure and mechanical properties of titanium joints. J Mater Process Tech 2009;209:4842-9.

[13] Shiue RK, Wu SK, Chen YT, Shiue CY. Infrared brazing of Ti50Al50 and Ti-6Al$4 \mathrm{~V}$ using two ti-based filler metals. Intermetallics 2008;16:1083-9.

[14] Jiang W, Gong J, Tu ST. A new cooling method for vacuum brazing of a stainless steel plate-fin structure. Mater Des 2010;31:648-53.

[15] Schwartz MM. Brazing. 2nd ed. USA: ASM; 2003.

[16] Metals Handbook, vol.6. Welding, brazing and soldering, USA: ASM; 1993

[17] Kang DH, Sun JH, Lee DM, Shin SY, Kim HS. Partially alloyed filler sheet for brazing of ti and its alloys fabricated by spark plasma sintering method. Mater Sci Eng A 2009;527:239-44.

[18] Matsu K, Miyazawa Y, Ariga T. Titanium brazing for manufacturing titanium heat exchangers. In: The preliminary program for 3rd international brazing and soldering conference (IBSC). San Antonio, April 23-26, 2006. p. 70-8.

[19] AWS A5.8. Specification for brazing filler metals for brazing and braze welding; 1992.

[20] JIS Z 3192. Methods for tension and shear tests for brazed joint; 1988.

[21] Shiue RK, Wu SK, Chan CH. The interfacial reactions of infrared brazing Cu and Ti with two silver-based braze alloys. J Alloy Compd 2004;372:148-57.

[22] Elrefaey A, Tillmann W. Brazing of titanium to steel with different filler metals: analysis and comparison. J Mater Sci 2010;45:4332-8.

[23] Elrefaey A, Tillmann W. Microstructure and mechanical properties of brazed titanium/steel joints. J Mater Sci 2007;42:9553-8.

[24] AWS C3.8. Recommended practice for ultrasonic inspection of brazed joints. 1997.

[25] Metals Handbook. Metallography and microstructures, vol 9. USA: ASM; 1998.

[26] Brandes EA, Brook GB. Smithells metals reference book. 7th ed. Oxford, (UK): Butterworth-Heinemann; 1992.

[27] Elrefaey A, Tillmann W. Brazing of titanium to steel with different filler metals: analysis and comparison. J Mater Sci 2010;45:4332-8.

[28] Metals hand book, vol. 3. Alloy phase diagrams: ASM; 1992.

[29] Yue X, He P, Feng JC, Zhang JH, Zhu FQ. Microstructure and interfacial reactions of vacuum brazing titanium alloy to stainless steel using an agcuti filler metal. Mater Charact 2008;59:1721-7.

[30] Liu CC, Ou CL, Shiue RK. The Microstructural observation and wettability study of brazing Ti-6Al-4V and 304 stainless steel using three braze alloys. J Mater Sci 2002;37:2225-35.

[31 Dieter GE. Mechnical metallurgy. 3rd ed. USA: Mc Graw hill; 2001.

[32] Hertzberg RW. Deformation and fracture mechanics of engineering materials. 4th ed. USA: John Wily \& Sons; 1996 